\title{
The Rhythms and Trends in Gift-Giving at Delphi
}

After setting the honorific culture in the broader context of epigraphic habit, it is now appropriate to investigate the value of gifts granted at Delphi. At any point throughout the Hellenistic and Roman periods, honours and privileges bestowed within the Delphic temenos varied in terms of the prestige they carried and the type of their intended recipient, as the Delphic honorific system shifted to adapt to the changing social milieu. In this chapter, I set out to analyse the assembled material and discuss the momentum and particulars of such shifts. The driving research questions which will be addressed are (a) whether the body of evidence supports the existence of trends or rhythms in gift-giving at Delphi, or whether the whole concept of honorific practice remained fairly fluid, and (b) how the selected body of evidence from Delphi informs our understanding of the Panhellenic honorific practice, 'the race for honours', and the dynamics of competition.

To address these questions, one must first consider the impetus behind the honorific practice itself and ask why the Greeks granted honours and privileges at all. The traditional answer to this question is that ' $[\mathrm{i}] \mathrm{n}$ the Greek world public honours were a way to reward citizens and foreigners for their benefactions as well as to encourage others to emulate the same virtuous conduct.' ${ }^{1}$ However, this understanding has been recently challenged by Domingo Gygax's studies on the origins of euergetism. As Domingo Gygax observes, honours did not simply serve as post-factum emblems of social recognition for one's contributions to the community, but they were also meant to elicit a response in the form of benefaction. In other words, gifts obliged recipients to reciprocate and elicited further and greater donations. When awarded in advance, honours held both the recipient and the granting community in a double bind. ${ }^{2}$ Honours thereby came to represent a kind of status-marking currency in the Hellenistic world which encouraged ever-increasing gestures of goodwill to both one's own city-state and foreign communities. ${ }^{3}$

1 Camia 2017, 109. See also Luraghi 2010, 248-252; Deene 2012, 171.

2 Domingo Gygax 2016, esp. 51-54.

3 On the procedure of granting honours, see Gauthier 1985, 77-128; Rhodes and Lewis 1997; Osborne 2012. 
As a public affair, the process of granting honours changed from period to period and from community to community. ${ }^{4}$ When judged from a distance, the honorific systems of different poleis may appear broadly similar but frequently they diverge once local idiosyncrasies are taken into account. In this connection, the honorific practice at the Delphic polis both followed and departed from traditions established by her neighbours. The goal of this chapter is to track these parallels and deviations in search of synchronic regularities and diachronic rhythms.

To begin with, I need to address the distinction between 'rhythm' and 'trend' within the analysis of honorific culture. In the following paragraphs, the term 'trend' denotes a general tendency that appeared at least once in the gift-giving system in a particular period but did not reappear later or was not subject to change. In contrast, we can speak about 'rhythms' when we describe epigraphic developments or variations characterised by their regular recurrence; therefore, rhythms are trends that reoccurred and became established. Every 'rhythm' changes and goes through several phases. Rhythms surface more easily within a rich epigraphic dossier, whereas samples of material which have a more limited scope, e.g. records of the honorific culture of foreigners at Delphi, predominantly display trends or tendencies. It is entirely possible, however, that trends would become rhythms if more epigraphic material had survived; as always, our perspective and understanding are only as good as the sources allow.

\subsection{Types, Value and the Hierarchy of Honours}

\subsubsection{The Amphictyony and Other Communities at Delphi}

The management of Delphi for centuries was bifocal. ${ }^{5}$ Clearly, the Delphic sanctuary had to be able to function on two levels at once, serving as a vehicle for both local and non-local ambitions. The territory of Delphi originally belonged to the chora of Kirra, but shortly after the First Sacred War, in the early sixth century BCE, it was confiscated and given to Apollo under the direct supervision of the Amphictyony, which had overarching responsibility for the sanctuaries of Apollo Pythios and Athena Pronaia throughout the

4 Heller and van Nijf 2017a, $5^{-8}$.

5 Davies $(1998,2-3)$ presents a brief sketch of the principal magistrates and administrative groups responsible for the management of Delphi. 
centuries that followed the war. ${ }^{6}$ Then, from the fourth to the second centuries BCE, it appears that much of this territory came into the private ownership of citizens of Delphi. ${ }^{7}$ With the passage of time, the distinction between sacred and secular Delphi blurred, which led to tensions between the city and the Amphictyony. ${ }^{8}$ The sanctuary was often treated as belonging to the polis, rather than as an interstate area. Many of the administrative posts within the sanctuary (such as the priests of Apollo and the Pythia herself) and within the Pythian Games (the president of the Pythian Games) were held by the citizens of the secular city of Delphi. ${ }^{9}$ The citizens of Delphi were also dispatched as theoroi by the Amphictyony some six months before the games were due to be held, in order to invite participants from throughout the Hellenistic world. ${ }^{10}$

Scholars have not yet fully investigated the degree and nature of interaction between the Delphic town and the Amphictyony. This chapter contributes to the discussion of the prerogatives of both the Amphictyonic council and the Delphic polis by showing that the rhythm of gift-giving at Delphi depended chiefly on decisions of the Delphic polis, partially on honorific practices of the Amphictyony, and, to a certain extent, on other Greek communities as well. To reconstruct the procedure by which foreign authorities granted honours at Delphi or the matters which those honours concerned poses considerable difficulties, since, among many well-preserved decrees, those granted by foreigners regrettably survive only in very damaged pieces. ${ }^{11}$ Those that have survived, however, allow us to trace certain consistencies and trends in decree-grants at Delphi. Within the Delphic temenos, foreign poleis bestowed noticeably fewer decrees than the Amphictyony. The honorific decrees voted by foreigners shows the significant Aetolian presence in Delphi and the close connections which existed between the League of the Aetolians and the

6 For the Amphictyony and its prerogatives in the sanctuary, see Sánchez 2oo1; Lefèvre 1998 and 2005, 9-34; Bowden 2003, 67-83; Hornblower 2007, 39-56; and Lefèvre 2011, 117-131 for a critical survey of the bibliography relative to the Delphic Amphictyony.

7 Rousset 1990, 15-17.

8 Weir 2004, 50-51.

9 The members of a few leading Delphic families regularly held both sacred and secular posts, see Grzesik 2018b, 124-13o.

$10 \quad$ Perlman 1995 and 2000.

11 CID 1.12 (36о вСЕ?); Syll 3306 (324 вСЕ), Syll 366 (292 вСЕ); FdD 3.214 and 215 (248-246 вСЕ); $S y l l^{3} 412$ and 413 (26о вСЕ); FdD 1.481 (255-245 ВСЕ), FdD 1.484 (25 ВСЕ), FdD 1.482 (246 вСЕ); $B C H$ 64/65.1940/1.10о (246 вСЕ); FdD 1.483 (25О-243 ВСЕ); Syll 479 (225 ВСЕ), Syll 499 (230 or 229 ВСЕ); FdD 3.145 (218-217 ВСЕ), FdD 4.132-135 (208 ВСЕ), FdD 1.353 (early second century BCE); $B C H$ 5.1881.404,14 (194-171 BCE); FdD 2.140 (190-150 вCE), $F d D$ 1.490-495 (3О-25 вСЕ), FdD 1.488 (30-25 ВСЕ), FdD 4.69 (87-85 вСЕ), FdD 1.485 (third century $\mathrm{CE}$ ?). 
Attalids. The citizens of Chios set up two honorific decrees for the Aetolians to thank them for accepting the Chians into the Amphictyony, ${ }^{12}$ whereas the decree of $183 / 2$ BCE showcases the ties between the League and the rulers of Pergamon. The League honoured Eumenes II of Pergamon with a golden horse statue and his family with a set of honorific portraits. ${ }^{13}$ This rather scant data on the decree-culture of foreign communities in Delphi can, however, be supplemented with information drawn from the town's rich statuary practice.

Significantly, the sampled material implies that the foreigners at Delphi preferred to honour members of their communities with statues rather than with decrees. As I mentioned in Chapter 1, among all statuary portraits, those granted by foreigners outnumber those granted by the Delphians at a ratio of 55/45. The majority of these portraits come from the period 279-19O BCE, when the League of the Aetolians ruled over Delphi, which testifies to the League's political influence. ${ }^{14}$ In this period the Aetolians erected 28 portraits in contrast to a mere four which were set up by the ostensibly independent Delphians. ${ }^{15}$ Contributions by other poleis at the Delphic temenos included private and public images set up by the Athenians ${ }^{16}$ (of which an entire group was granted for members of the Herodes Atticus family), ${ }^{17}$ the images of the representatives of the Boeotian koinon and poleis, ${ }^{18}$ and monuments set up by the citizens of Phokis and the Achaean League. ${ }^{19}$ The fame of Delphi also attracted benefactors from far-removed communities, with surviving images granted by the citizens of Cyprus, ${ }^{20}$ Kyzikos, ${ }^{21}$ Ephesos, ${ }^{22}$ Alexandria in Egypt, ${ }^{23}$ as well as by royalty, such as Dropion, the king of Paeonia who praised his father (or grandfather?) at Delphi, ${ }^{24}$ and Nereis, the princess of Epirus. ${ }^{25}$

\footnotetext{
$12 F d D_{3.214}$ and 215 (248-246 BCE). Lefèvre 1998, 116-117; Sànchez 2001, 297-298.

$13 \quad F d D 3.240$.

14 Grzesik 2019, 208-210.

15 As a comparandum, during the period of the Athenian control over Delos, Athenian statues also dominated the Delian monumental landscape. See Herbin 2014a, 21-33.

$16 \quad F d D$ 4.224 [2]; $B C H$ 85.1961.88. On Athenian relations with Rome under Augustus, see Stamires 1957, 26o and Benjamin, Raubitschek 1959, 65-85; Schmalz 2009; Spawforth 2011.

17 FdD 3.66-74. See Choix 2012, nos. 256-264; Ameling 1983, nos. 103-110 and 176. For Atticus' statues in Olympia, see Bol 1984. For Atticus' monuments in Athens, see Tobin 1997.

18 Klio 15.1918.53-4; FdD 4.463, FdD 1.519.

$19 F d D$ 1.47. See Choix 2012, no. 153; Jacquemin 1999, no. oo5; Muller-Dufeu 2002, no. 2346.

$20 \quad F d D$ 1.547.

$21 \quad B C H$ 116.1992.18o-183; FdD 1.513, FdD 4.209. See Marcadé 1953, I 34; Jacquemin 1999, no. 135; Muller-Dufeu 2002, no. 2015; Choix 2012, no. 5 .

$22 \quad F d D 4.265$.

$23 \quad B C H 49.1925 .81-82$.

$24 \quad B C H 74.195^{\circ} .22$ and $B C H 76.195^{2.138 . ~}$

$25 \quad F d D$ 4.235.
} 
The epigraphic dossier of the Amphictyony, which comprises over no decrees and 31 tituli honorarii, dwarfs the epigraphic footprint of foreign communities and thereby reveals a series of thought-provoking patterns. The earliest honorific decrees voted by the Amphictyony come from the mid-fourth century вСE. Subsequently, the Amphictyonic and Delphic decree cultures co-develop, with the acme of Amphictyonic decree culture being dated to the third century вСЕ. ${ }^{26}$ One of the first surviving documents concerns the granting of titles of euergetai to the citizens of Messenia and Megalopolis. ${ }^{27}$ Over time, the range of bestowed honours widened, with prodikia (right to priority in a trial) and asphaleia (assurance from danger, guarantee of personal safety) most frequently attested in the material. Sánchez observes that the Amphictyonic honorific practice in the third century BCE already centred around a group of preferentially granted distinctions, namely prodikia, asphaleia, asylia (immunity from the right of reprisal), ateleia (exemption from public burdens), and proedria (a standing reservation of best seats at the theatre). ${ }^{28}$

More interesting than the privileges granted, however, are those that were never bestowed by the Amphictyony, even though they are widely attested in other poleis. Examples of this kind include promanteia (precedence in consulting an oracle), politeia (citizenship), theorodokia (privilege of hosting the sacred ambassadors of states who organise games and festivals), bouleuteia (membership in the civic council) and enktesis (tenure of land in a foreign polis). As a supra-local organisation, the Amphictyony did not grant bouleuteia, politeia or enktesis because these honours conferred status in only a single polis, so they are considered as typical 'city-privileges'. The telling absence of promanteia among the privileges bestowed in the Amphictyonic decrees highlights the differing prerogatives exercised by both the Amphictyony and the Delphic polis within its sanctuary and oracle. The epigraphic documents show that only the Delphians had the authority to grant any person precedence in consulting their oracle, this being one of the oldest and most frequently granted privileges, which is attested in over $80 \%$ of Delphic decrees. ${ }^{29}$

The bestowal of proxenia also stands out in the sample as it is attested in only one Amphictyonic decree for Kallistos, dated to 48 вСЕ. ${ }^{30}$ To explain its rarity, we need to consider how far the authority of the Amphictyony could have extended. Lefèvre argues that there were three possible levels at which the

\footnotetext{
$26 \quad$ Chapter 1.

27 CID 4.7 (346/5 вCE ?).

28 Sánchez 2001, 318.

29 Sánchez 2001, 71-72.

$30 \quad$ CID 4.13o. For the definition of proxenia, see Chapter 3.
} 
decision of the Amphictyony could apply: the local (limited to the sanctuary); regional (limited to the territory of the members of the Amphictyonic League); and the Panhellenic level..$^{31}$ In this particular case, Kallistos was expected to host ambassadors from both the Amphictyonic member states and the other poleis (the Panhellenic context), while being praised as the proxenos and euergetes on behalf of not only the Amphictyonic council but also all Greeks ( $\varepsilon i v \alpha$ l

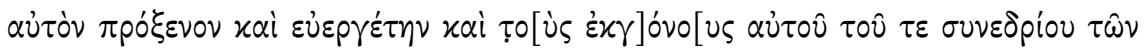

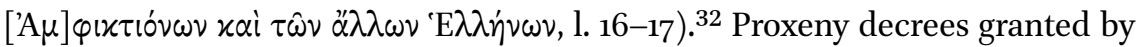
supra-local organisations, although rare, have comparanda in other regions. For example, Timos of Syracuse became the proxenos of the koinon of Nesiotes, ${ }^{33}$ while the Achaean League granted a federal proxeny decree, alongside asylia and ateleia, to hostages from Boeotia and Phokis. ${ }^{34}$ There are even more remarkable testimonies of granting proxenia by non-communal actors, such as dynasts and pettykings. A rare example comes from the Bosporan kingdom where, in the fourth century $\mathrm{BC}$, the Bosporan kings issued a series of proxeny edicts. ${ }^{35}$ Similar grants were issued by Mausolos, Satrap of Karia, the dynast of Paphlagonian Korylas, and Korris, the priest-prince of Labraunda. ${ }^{36}$

In the sample of honours granted by the Amphictyony in the period under discussion, the limited number of grants of proxenia and euergesia together with the total absence of theorodokia demonstrate that the Amphictyony, in contrast to the Delphic polis, did not use honorific culture to create an international network of mutual obligations in an especially far-sighted way. ${ }^{37}$ Nonetheless, the Amphictyonic honorific habit displays at least three discernible pragmatic trends in gift-giving. The first trend (1), which is strictly honorific, centres on the giving of gifts of honorary character, such as proedria, commendation, crowns, statues and xenia. These gifts of symbolic value satisfied the recipient's philotimia but did not confer any economic or political profits. In contrast, the second trend (2) concerns the granting of privileges which provide the honorands with palpable economic benefits, such as prodikia, asylia, ateleia and asphaleia. As was typical to the Hellenistic period, this trend in the Amphictyonic-controlled gift-giving system manifests itself chiefly in the form of formulaic packages of economic honours bestowed in the third century decrees. Finally, the last tendency (3) is 'the asylia trend', which is first attested

\footnotetext{
31 Lefèvre 2002, 328.

32 Sànchez 2001, 422-424.

$33 I G$ XII,5 817.

34 Rizakis 2008, 118.

35 CIRB 1-5; Cojocaru 2016, 91-10o.

36 Mack 2015, 229-230.

37 See below.
} 
in 262/1 BCE, when the Amphictyony granted asylia to the sanctuary of Athena Itonia. Subsequently, a series of decrees granted asylia to different Greek sanctuaries over the next fifty years, in the period between 225 and 182 BCE. ${ }^{38}$

\subsubsection{The Delphic Gift-Giving System}

As an introduction to the Delphic honorific system, Bouvier's seminal study (1978) usefully presents the various types of honours and privileges attested in 522 Delphic honorific decrees. ${ }^{39}$ The author enumerates twenty-two types of privileges issued by the citizens of Delphi: proxenia (right to host foreign ambassadors at one's own expense), promanteia (the right to priority in consulting an oracle), proedria (a standing reservation of best seats at the theatre), prodikia (the right to priority in a trial), asylia (immunity from the right of reprisal), ateleia (exemption from public burdens), theorodokia (privilege of hosting the sacred ambassadors of states organising games and festivals), euergesia, epitimia (enjoyment of all civil rights and privileges), citizenship, bouleuteia, asphaleia (assurance from danger, state guarantee of personal safety), commendation, enktesis (tenure of land in a foreign city), crown, isopoliteia, invitation for a public meal, erection of the statue, sending xenia, epinomia/pronomia (the right of pasture), propompeia (the first place in a procession), and prothysia (priority in sacrifice). ${ }^{40}$ Although impressive in its detail, Bouvier's study has certain limitations. Bouvier's chief interest in Delphi lies in decree formulae and the relative ordering of honours within the decree text. Accordingly, he does not engage in any kind of qualitative analysis. Furthermore, he omits parts of the available epigraphic dossier, such as a decree granting hero worship, ${ }^{41}$ and he erroneously separates epinomia from pronomia, which are synonyms for a single type of privilege. ${ }^{42}$ Despite these

$38 \quad$ CID 4.38 asylia for the sanctuary of Athena Itonia. See also CID 4. 76, CID 4.77, CID 4.97, CID 4.99, CID 4.107. Cf. Sànchez 2001, 335-359.

39 Bouvier 1978, 101-118.

40 Bouvier 1978, 101-102. Bouvier's list includes twenty-three privileges, owing to the fact that he distinguishes between pronomia and epinomia, see fn. 42 in this chapter.

$41 \quad F d D 1.466$.

42 Bouvier defines epinomia merely as 'droit de pâture' (the right of pasture), ignoring pronomia altogether $(1978,102)$. The Liddell-Scott-Jones dictionary defines epinomia and pronomia as synonyms referring to granting of the right of pasturage $\left(L S J^{9}\right.$ s.v. $\pi$ povoria -

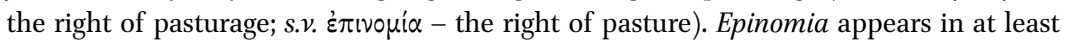
six documents from Delphi, five of which date to the third century BCE and one to the beginning of the second century вСЕ (FdD 4.175; SGDI 2672; Syll ${ }^{3} 534$ and $534 \mathrm{~B} ; F d D 4.427$ $B$ IV-reconstructed, $F d D$ 1.451). In contrast, a pronomia decree is preserved in a single text dated to $121 \mathrm{CE}(F d D$ 4.84). See Kyriakidis 2019, 107. 
flaws, the study constitutes a reliable basis on which I build by addressing matters omitted or mentioned only in passing by Bouvier.

With regard to the number of decrees analysed for this study, the total number of attested decrees from Delphi is, minimally, 1184, if one includes decrees voted by the Delphic polis, Amphictyony and other communities, as well as texts by unknown granting authorities. ${ }^{43}$ Crucially, this figure includes all known decrees and not simply intact and/or legible ones, with the contents of many decrees being either fragmentary, reconstructed through inferred parallels, or irretrievably lost. By removing spurious reconstructions and irreparably damaged texts, I ended with a study sample of $c$. 103 o honorific documents, encompassing 9oo Delphic honorary decrees which show an intact list of honours granted and 127 tituli honorarii which concern the granting of statues set up by the citizens of Delphi. Although somewhat lower than the initial number, the reduced study sample will more than suffice to ascertain whether the Delphic honorific habit shifted in time. The following bar graphs demonstrate the main quantitative trends and rhythms in the epigraphic record at Delphi. The first (Figure 9) presents honours granted by the Delphic polis in descending order of frequency, whereas the second shows the chronological distribution of specific types of grants (Table 3).

Proxenia, the most popular type of decree in Athens, Delos and Oropos, unsurprisingly constitutes the vast majority of honours in Delphic decrees. ${ }^{44}$ Other frequently granted honours, often bundled and granted simultaneously (as 'a package of honours') in the Hellenistic period, were promanteia, proedria, ateleia, prodikia and asylia. The recurrent bundling of these grants influenced the standard formula of the abbreviated Delphic decree $(\Delta \varepsilon \lambda \varphi$ oi $\varepsilon \delta \omega x \alpha \nu . .$.

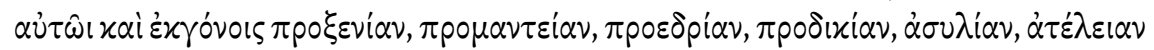

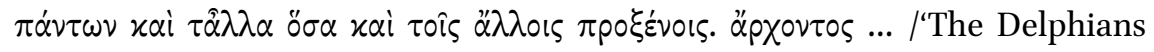
gave ... him and his descendants proxenia, promanteia, proedria, asylia, ateleia, and he is to have everything else that is given to other proxenoi.... was an archon').$^{45}$ The chosen sample reflects the popularity of the 'package' in both the Delphic and Amphictyonic parts of the collection at Delphi (with a slight prevalence of prodikia, asylia, ateleia, asphaleia and proedria grants for the Amphictyony-issued decrees). These honours thus defined the honorific habit in Delphi in the Hellenistic era.

43 Chapter 1.

44 Domingo Gygax 2016, 111; Constantakopoulou 2019, 87.

45 E.g. $F d D$ 1.12, $F d D$ 1.17, $F d D$ 1.42. Grzesik 2013, 157-162. See Chapter 5.1.1. Translations of inscriptions are my own unless noted otherwise. 


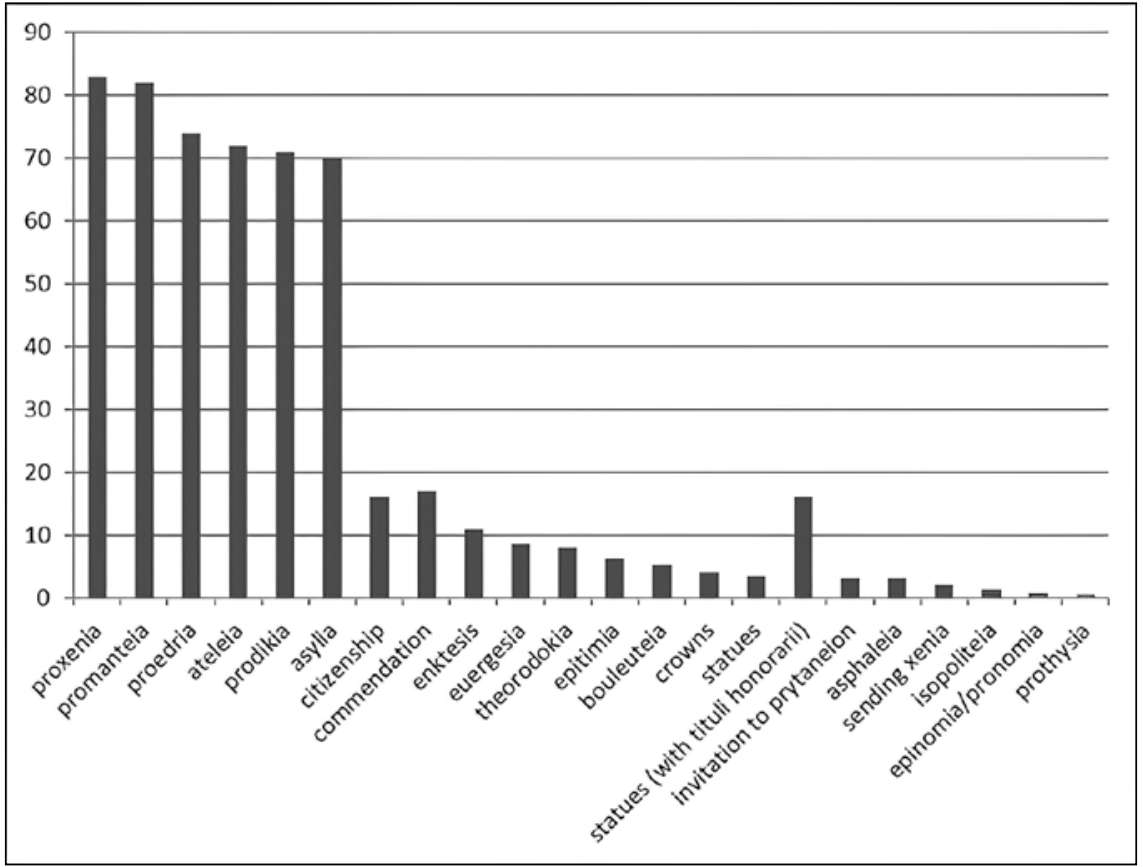

FIGURE 9 Types of honours granted by the Delphic polis, in descending rhythm of frequency (by percentages of the study sample)

Note: As an important aside, Figure 9 excludes grants of hero worship and propompeia, both types of decrees which were granted only once in Delphi. Hero worship features in one decree, $F d D$ 1.466. Propompeia appears in a fragmentary (and reconstructed) decree of $106 \mathrm{BCE}(F d D$ 2.49), whose reconstruction is based on the text of a letter from the same year $(F d D 2.48)$. Grants of statues account only for $3,5 \%$ of Delphic honorific decrees; statues counted with tituli honorarii, however, constitute $16 \%$ of the total.

The second most frequently-cited type of gift after the standard 'package of honours' was the erection of statues from the classical period onwards within the sanctuary landscape. Awarded as early as in the fifth century BCE, honorary statues within the Delphic temenos were initially set up solely by foreigners. The earliest statues by Delphic citizens date to the third century вСЕ, yet their number remained small for over a century. The local statuary habit developed only after Delphi freed itself from the Aetolian domination, and is attested until the late fourth century $\mathrm{CE} .{ }^{46}$

Commendation, which is often presented as the most universal honour awarded by Greek poleis, came down to us only in full pattern decrees and 
TABLE 3 Chronological distribution of specific types of grants

\begin{tabular}{|c|c|c|c|c|c|c|c|c|}
\hline & $\begin{array}{l}4^{\text {th }} \\
\text { c. BCE }\end{array}$ & $\begin{array}{l}3^{\text {rd }} \\
\text { c. BCE }\end{array}$ & $\begin{array}{l}\text { 2nd } \\
\text { с. BCE }\end{array}$ & $\begin{array}{l}\text { 1st } \\
\text { c. BCE }\end{array}$ & $\begin{array}{l}\text { 1st } \\
\text { c. CE }\end{array}$ & $\begin{array}{l}\text { 2nd } \\
\text { c. CE }\end{array}$ & $\begin{array}{l}3^{\text {rd }} \\
\text { c. CE }\end{array}$ & $\begin{array}{l}4^{\text {th }} \\
\text { c. CE }\end{array}$ \\
\hline statues & & $\mathrm{x}$ & $\mathrm{x}$ & $\mathrm{x}$ & $\mathrm{x}$ & $\mathrm{x}$ & $\mathrm{x}$ & $\mathrm{x}$ \\
\hline proxenia & $\mathrm{x}$ & $\mathrm{x}$ & $\mathrm{x}$ & $\mathrm{x}$ & $\mathrm{x}$ & $\mathrm{x}$ & & \\
\hline promanteia & $\mathrm{x}$ & $\mathrm{x}$ & $\mathrm{x}$ & $\mathrm{x}$ & $\mathrm{x}$ & $\mathrm{x}$ & & \\
\hline proedria & $\mathrm{x}$ & $\mathrm{x}$ & $\mathrm{x}$ & $\mathrm{x}$ & $\mathrm{x}$ & $\mathrm{x}$ & & \\
\hline ateleia & $\mathrm{x}$ & $\mathrm{x}$ & $\mathrm{x}$ & $\mathrm{x}$ & $\mathrm{x}$ & $\mathrm{x}$ & & \\
\hline prodikia & $\mathrm{x}$ & $\mathrm{x}$ & $\mathrm{x}$ & $\mathrm{x}$ & $\mathrm{x}$ & $\mathrm{x}$ & & \\
\hline asylia & $\mathrm{x}$ & $\mathrm{x}$ & $\mathrm{x}$ & $\mathrm{x}$ & $\mathrm{x}$ & $\mathrm{x}$ & & \\
\hline citizenship & $\mathrm{x}$ & $\mathrm{x}$ & $\mathrm{x}$ & $\mathrm{x}$ & $\mathrm{x}$ & $\mathrm{x}$ & $(\mathrm{x} ?)$ & \\
\hline commendation & $\mathrm{x}$ & $\mathrm{x}$ & $\mathrm{x}$ & $\mathrm{x}$ & $\mathrm{x}$ & $\mathrm{x}$ & & \\
\hline enktesis & $\mathrm{x}$ & $\mathrm{x}$ & $\mathrm{x}$ & $\mathrm{x}$ & $\mathrm{x}$ & $\mathrm{x}$ & & \\
\hline asphaleia & $\mathrm{x}$ & $\mathrm{x}$ & $\mathrm{x}$ & $\mathrm{x}$ & $\mathrm{x}$ & $\mathrm{x}$ & & \\
\hline euergesia & $\mathrm{x}$ & $\mathrm{x}$ & $\mathrm{x}$ & $(\mathrm{x} ?)$ & $(\mathrm{x} ?)$ & & & \\
\hline theorodokia & $\mathrm{x}$ & $\mathrm{x}$ & $(\mathrm{x} ?)$ & $(\mathrm{x} ?)$ & & & & \\
\hline epitimia & $\mathrm{x}$ & $\mathrm{x}$ & & & & & & \\
\hline bouleuteia & & & & & $\mathrm{x}$ & $\mathrm{x}$ & $(\mathrm{x} ?)$ & \\
\hline crowns & & $\mathrm{x}$ & $\mathrm{x}$ & $\mathrm{x}$ & $\mathrm{x}$ & $\mathrm{x}$ & & \\
\hline invitation to the & & & $\mathrm{x}$ & $\mathrm{x}$ & & & & \\
\hline \multicolumn{9}{|l|}{ prytaneion } \\
\hline sending xenia & & & $\mathrm{x}$ & $\mathrm{x}$ & & $(\mathrm{x} ?)^{\mathrm{a}}$ & & \\
\hline isopoliteia & & $\mathrm{x}$ & $\mathrm{x}$ & $\mathrm{x}$ & $\mathrm{x}$ & & & \\
\hline epinomia/pronomia & & $\mathrm{x}$ & $\mathrm{x}$ & & & $\mathrm{x}$ & & \\
\hline prothysia & & $\mathrm{x}$ & $\mathrm{x}$ & $\mathrm{x}$ & & & & \\
\hline hero worship & & & & & & $\mathrm{x}$ & & \\
\hline propompeia & & & $\mathrm{x}$ & & & & & \\
\hline
\end{tabular}

a The bestowal of sending xenia is attested only in documents dated to the second and first centuries ВСЕ, with a possible exception of one fragmentary decree dated to the second century CE. The latter identification remains uncertain: the pattern of the decree resembles those issued by the Delphic polis $(F d D 1.263 \mathrm{~b})$, with a lacuna over the name of the authority granting the honour.

make up $71 \%$ of this class. ${ }^{47}$ What is notable, however, is that public praise was never granted in abbreviated decrees. Consequently, it appears in only $17 \%$ of all documents.

47 Gengler 2017, 31-55. 
The Roman conquest brought several changes to the Delphic gift-giving system. As Table 3 demonstrates, the transformation of the honorific habit under the Romans occurred gradually and becomes visible only following close scrutiny of the data. A more thorough analysis of the Roman-era sample indicates that the honorific procedure at Delphi in the imperial period underwent both quantitative and qualitative changes. First, as noted in Chapter 1, long and formal honorific decrees, typical of the Hellenistic times, were largely replaced by much briefer tituli honorarii in the imperial era. Although other types of privileges were still occasionally conferred in Greece and in Delphi under the Romans, their numbers dropped sharply, with traceable increases noted in the number of awarded honorific statues (Chapter 1, Figure 6).

The second development in the Delphic honorific habit in the imperial period concerns the awarding of Delphic citizenship, with this number rising greatly in the first and second centuries CE.

Many contemporary documents attest to the ongoing depopulation of Delphi under the Romans. ${ }^{48}$ To counteract these developments, the polis increased its citizenry by granting citizenship on an unprecedented scale (Figure 10). The resultant replacement of the ruling elite and the sheer number of awarded citizenship grants brought about the devaluation of citizenship status. Significantly, citizenship grants in the preceding classical and Hellenistic periods have tended to be considered as 'honorary', 'potential', or 'virtual'.49 The main advocates of this thesis, Gauthier and Osborne, suggest that, in order to obtain full politeia, one had to be officially enrolled into demes or phyle. ${ }^{50}$ Regardless of the character of Delphic politeia in the Hellenistic period, in the Roman period the process of devaluation of Delphic citizenship seems to have continued apace. From the first century CE onwards, citizenship alone was not sufficient to qualify a citizen to hold office, for which a further level of qualification was introduced. Family origin and wealth became additional qualifications, as is clearly demonstrated in the Telesagoros case. ${ }^{51}$ This decree reveals that, already in the mid-first century CE, the Delphic citizen body was

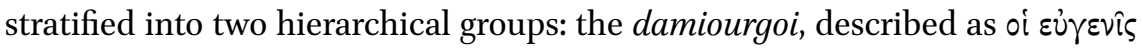

$48 \quad F d D$ 4.286 (52 CE). Sartre 1991, 233-237; Alcock 1993.

49 Mack 2019, 61-82.

50 Osborne 1983, 141-142 (vol. 4); Gauthier 1985, 150-152. The following scholars discuss in greater detail grants of citizenship, the evidence for the enrolment of new citizens and holders of multiple citizenships in the Hellenistic era: Savalli 1985, 387-431; Müller 2014, 753-775, 2015, 355-370 and 2016, 281-294. Blok (2017) argues that, apart from political identity, Athenian citizenship also conferred a religious identity on its holders. FdD 4.442 (mid-first century CE). Cf. Nouveau choix 2005, 82-84, no. 13; Choix 2012, 407408, no. 224. 


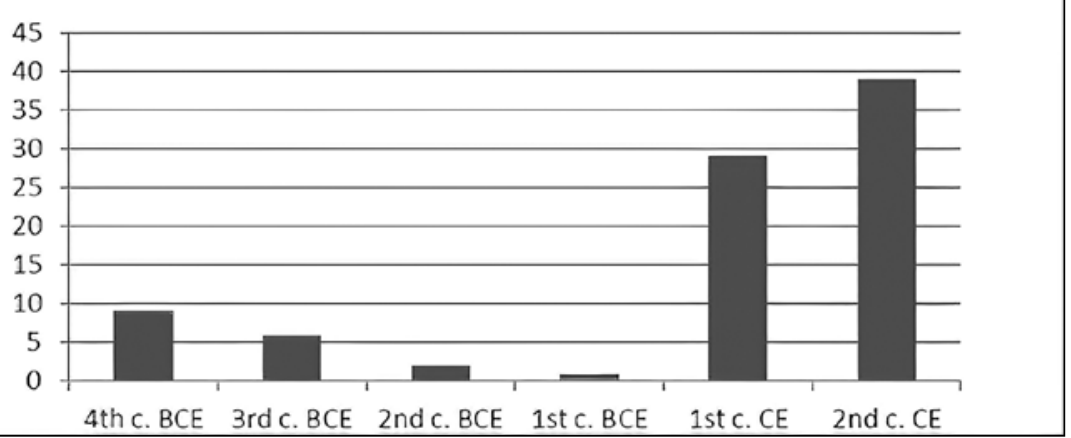

FIGURE 10 The number of grants of citizenship at Delphi (fourth century BCE-second century CE)

$\Delta \varepsilon \lambda \varphi \omega \hat{\omega} /$ 'well-born Delphians', who had exclusive access to the highly desira-

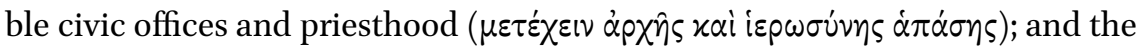
remainder of the citizens, who were barred from assuming these positions. ${ }^{52}$ Furthermore, the inscription identifies two levels of citizenship, namely the upper level (politeia) and the lower one (koine). The latter is described as being

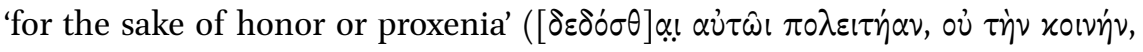

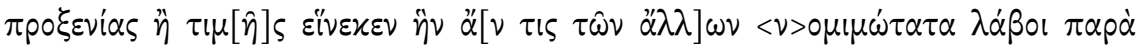
$\Delta \varepsilon \lambda \varphi \hat{\omega} \nu) .53$

The third development in the Delphic honorific habit in the imperial period concerns the appearance of a new type of privilege, bouleuteia, at the end of the first century CE. 42 honorific decrees attest bouleuteia as a new privilege which allowed individuals to both serve as a councillor and belong to the ruling class of Delphi. ${ }^{54}$ A relevant law of $135^{-13} 8 \mathrm{CE}$ regulating the allocation of land at Delphi also mentions bouleutai as a separate class, although their hierarchical relation (or any connection) to the damiourgoi is left unclear. ${ }^{55}$ Citizenship

52 Already in the mid-second century ВСЕ, one manumission inscription mentions damiourgoi at Delphi; nonetheless, nothing survives regarding their social significance, membership requirements or prerogatives, SGDI 2189 (150-140 BCE). See Vatin 1961, 236-255; Vatin 1970, 259-263; Ferrary and Rousset 1998, 297-299; Hamon 20o9, 373-378. For damiourgoi in other Greek poleis, see Veligianni-Terzi 1977, 51-55 and 9o-96; Zoumbaki 20o1, 90-95.

53 Vatin 1961, 239; Grzesik 2018b, 118-120.

54 The earliest documents are dated to the end of the first century CE $(F d D 2.98, F d D 4.114$ and 115).

55 Ferrary and Rousset 1998, 277-342. Bouleutai are also attested as a separate upper class in Sillyon in Pamphylia (IGR III 800 and 801), and Poglia in Pisidia (IGR III 409), see Sartre 1991, 141-142. For concurrent transformations of the city council and the social status of bouleutai, see Hamon 2005, 121-144; Grzesik 2018b, 123-124. 
and bouleuteia were issued at least until the late second/early third century $\mathrm{CE}$, with their terminus ante quem generally dated to $c .175^{-225} \mathrm{CE} .{ }^{56}$ Nonetheless, a remarkably late citizenship decree for a pantomime dancer (Aurelius Neikon of Aigina) and his sons indicates that politeia grants were occasionally issued in the mid-third century CE. ${ }^{57}$

Lastly, it is interesting to look in network terms at what happened with the Delphic gift-giving system when Rome became the dominant power in the Mediterranean. ${ }^{58}$ Already from the late Hellenistic period onwards, the Delphic statuary habit increasingly revolved around grants to Roman citizens, with $46 \%$ of all images being granted to high-ranking Roman magistrates between 19 о ВСЕ-27 ВСE. Simultaneously, Delphi's interactions with the Greek poleis dwindled during this time. The network of mutual obligations within and outside Delphi not only prioritised Roman citizens but also became increasingly parochial, excluding grantees from other communities, especially in Asia Minor or Africa, regions that previously were frequently attested in pre-Roman Delphic decrees. The number of foreign honorands also diminished under the Romans, with the remaining foreign honorands mostly being made up of inhabitants of mainland Greece. ${ }^{59}$

At the same time, profound structural changes in the Delphic network system occurred through the mass granting of honorific titles of proxenoi, euergetai and theorodokoi. ${ }^{60}$ Not only did these grants confer prestige but they also established a dense network of bonds of reciprocal obligation between citizens of various Greek poleis. ${ }^{61}$ At some point in the mid-fourth century вСE, the citizens of Delphi began to confer these three types of honorific titles upon prominent foreigners. ${ }^{62}$ Theorodokoi were sacred envoy-receivers whose duty was to host and assist foreign delegations (theoroi) of the state which was about to organise a Panhellenic Game or a festival. Their duties paralleled those of proxenoi but, unlike the permanently officiating proxenoi, theorodokoi performed their role only before the individual set of games and festivals. ${ }^{63} \mathrm{~A}$ continuous record of theorodokia at Delphi exists for the entire third century BCE, although no direct grants of theorodokia survive in the sample dated to the second and first centuries BCE. Nevertheless, the sampled material indirectly implies that

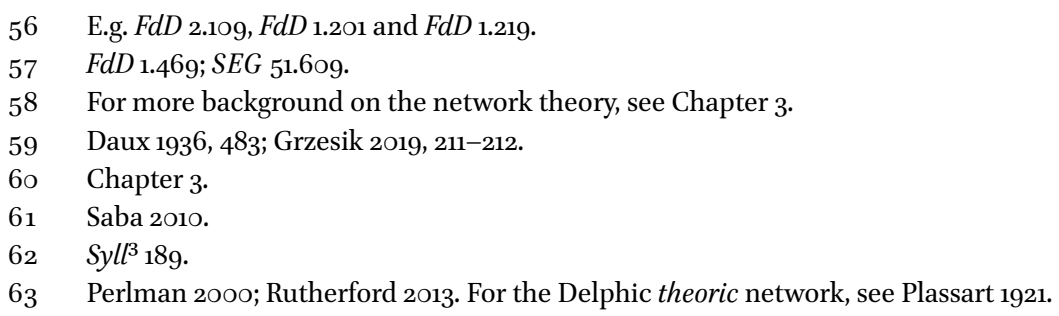


theorodokia was granted in late-Hellenistic Delphi: motivation clauses in several decrees mention that the recipients of the awarded honours performed as theorodokoi of the Pythian Games and/or the Soteria festival. ${ }^{64}$ With fewer and fewer grants of this type being awarded, the significance of theorodokia in Delphi and abroad dwindled rapidly. Mirroring the dip of this honour at Delphi, direct grants of theorodokia disappear in the late first century вСЕ from the epigraphic material gathered in other poleis. ${ }^{65}$

Euergesia, the second type of privilege assigned to the creation of Delphi's network, has a complicated epigraphic record. Its earliest and latest epigraphic testimonies date respectively to the early fourth century ВСЕ and the midpoint of the second century вСЕ. ${ }^{66}$ The granting of euergesia, although no longer named as such, could have been awarded at least until the early imperial period (specifically, the first half of the first century CE), since a part of the standard

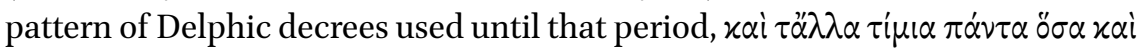

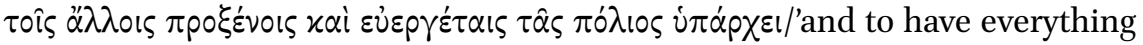
else that is given to other proxenoi and euergetai', indicates that euergetai might have still existed as a class, even if euergesia was not the subject of individual grants. ${ }^{67}$ Nevertheless, the standard decree pattern possibly reflects the fossilised formula that served to describe one's deeds, and does not necessarily prove that euergesia did not disappear from the epigraphic record after the Hellenistic period.

The third type of honorific title that shaped Delphi's foreign policy, proxenia, likewise loses its potency in forging international bonds by the Roman period. ${ }^{68}$ In contrast to euergesia and theorodokia, the Delphic polis awarded proxeny grants until the second century CE. In spite of this, a Roman-era grant of proxenia at Delphi meant much less than one granted in the earlier periods, since the social infrastructure behind the sacred hospitality had eroded into oblivion by this point. In the Hellenistic period, grants of proxenia usually came first in the list of honours awarded in Delphi. ${ }^{69}$ At some point in the early first century CE the format of Delphic proxeny decrees changed. According to Mack, the grant of proxenia became '[a]n undistinguished, probably antiquarian, honorific title without particular content or significance. Proxenia is simply an extra item in the list of honours, occurring not only after politeia

\footnotetext{
$64 \quad F d D 1.15^{2}$ (c. 150/149 ВСЕ), $F d D 2.55$ (8О ВСЕ), $F d D$ 1.318 (49/8-48/7 ВСЕ).

65 Perlman 200o, 26-27; Mack 2015, 257.

66 One of the earliest decrees is $B C H$ 23.1899.526 (bef. 373 вСЕ?). See also $F d D 1.14$ (161/O BCE), FdD 1.151 (159/8 вCE), FdD 1.154 (c. 145 ВCE).

$67 \quad$ E.g. $F d D 2.16$ o (23 CE). Mack 2015, 243-244.

68 Mack 2015, 243-254; Zoumbaki 2017, 252.

69 Bouvier 1978, 101-118.
} 
but even promanteia or proedria, a sure sign that it was no longer understood as signifying a particular relationship. ${ }^{70}$ By the imperial period, the granting of proxenia followed the pattern of theorodokia and euergesia. It no longer signified any operative social relationship and, consequently, ceased to exert any influence over the civic foreign policy. A similar devaluation of proxenia occurred in the Greek communities in the Black Sea region, where, in the first and second centuries $\mathrm{CE}$, grants of proxenia were subsumed under politeia. ${ }^{71}$

The disappearance of honorific titles that typically forged international bonds of obligation in the late classical and Hellenistic periods testifies to the loosening of social networks in Delphi, and Greece in general, in the imperial period. Other forms of Greek peer-polity interactions, such as invitations to the prytaneion and sending xenia, also show a decline in their number in Roman Delphi (Table 3). It is also worth noting that these two types of honours were commonly awarded to foreign judges and ambassadors. ${ }^{72}$ For example, inviting foreign ambassadors for a public meal was a common practice in Athens. ${ }^{73}$ In Delphi, the most prominent envoys invited to the prytaneion included Bias, an envoy of the king Nikomedes ${ }^{1 I I},{ }^{74}$ ambassadors and theoroi from Knidos, ${ }^{75}$ and envoys from Tetrapolis. ${ }^{76}$ Other recipients of these honours were foreign judges from Megalopolis, ${ }^{77}$ Sparta, ${ }^{78}$ Lilaia, ${ }^{79}$ Thebes, ${ }^{80}$ Hermion $^{81}$ and Teithronion. ${ }^{82}$ The epigraphic record of the second century BCE shows that xenia ( $\xi \dot{\varepsilon} v i \alpha \tau \dot{\alpha} \mu \dot{\varepsilon} \gamma(\sigma \tau \alpha \dot{\varepsilon} \varkappa \tau \hat{\omega} \nu$ vó $\mu \omega \nu$ ) was granted to ambassadors from Chersonesos (who had helped Delphic envoys when they were kidnapped by pirates), ${ }^{83}$ ambassadors from Sardis that asked for the Delphic recognition of two new festivals, ${ }^{84}$ and foreign judges from Lilaia, ${ }^{85}$ Opous ${ }^{86}$

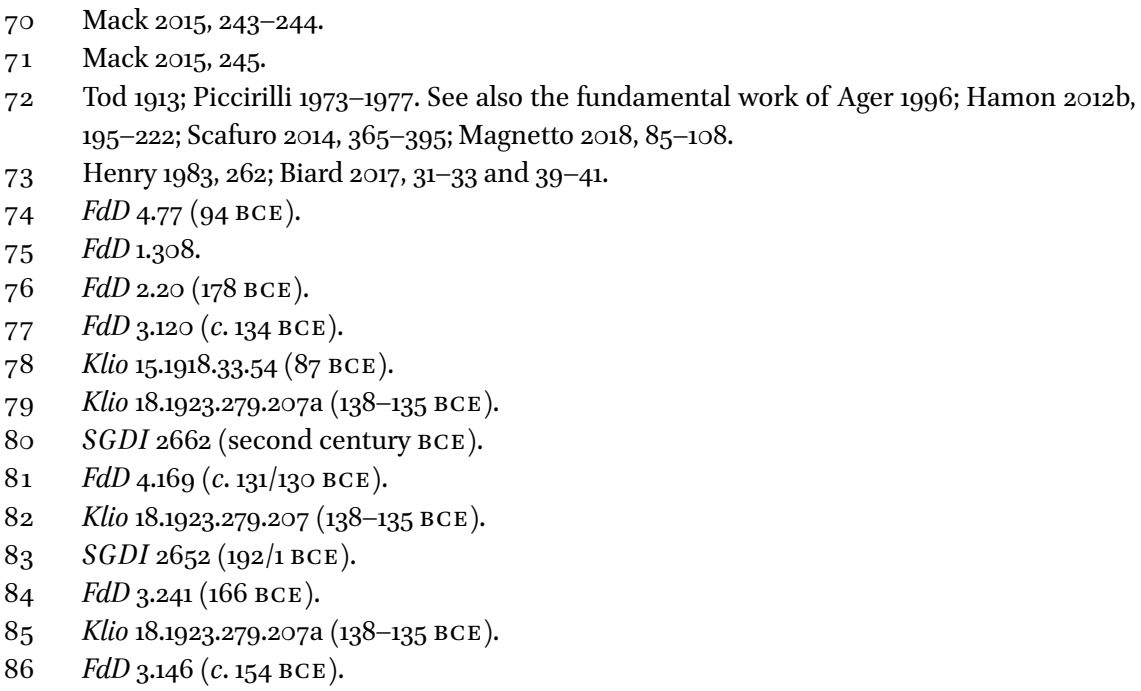


and Rhodes. ${ }^{87}$ Over the course of the first century BCE, decrees mentioning the activity of foreign judges almost disappear in Greece, but the practice of sending courts continued in some regions down to the second century CE. ${ }^{88}$ The change in the practice of inscribing this type of decree can be interpreted in various ways. Some scholars attribute it to the presence of Roman governors, who could now fulfill the role previously played by foreign judges. ${ }^{89}$ The increasingly Romanocentric social network had no need for peer-to-peer arbitration practices, which in turn obviated the need for granting honours that would establish such ties in the first place. Another possibility, which has been raised by Magnetto, is that changes in the epigraphic habits of the Greek cities under the Roman empire, which tended to produce fewer public documents than before, may explain the relative absence of evidence for the activity of foreign judges. This change may even suggest a shift in attitudes of the polis towards an institution that was so familiar that it no longer drew interest and was therefore not mentioned in public decrees. ${ }^{90}$

In conclusion, the available evidence attests to the existence of several gift-giving rhythms and trends in the honorific system in Delphi. Certain honours remained popular for many centuries that shaped Delphi's interstate interactions, such as proxenia (granted from the mid-fourth century вСЕ to the late second century $\mathrm{CE}$ ), to the extent that we can distinguish a separate 'proxeny rhythm' at Delphi. This rhythm is characterised by varying intensity and goes through at least two phases in its existence (waxing and waning); for example, the proxeny rhythm in the Hellenistic period was one of the most important honorific rhythms at Delphi, while it visibly lost its prestige in the imperial period. The second rhythm is the so-called theoric or festival rhythm. ${ }^{91}$ The practice of granting honorific portraits should also be catalogued as a rhythm with many discernible turns and phases, which is particularly visible in the ongoing deflation of this honour. ${ }^{92}$ Rhythms and trends can also be distinguished within the types of the recipients of Delphic honours. The appearance of the Macedonians and the Romans in the honorific habit, who were not previously granted any Delphic privileges, reflects a major geographical shift in the gift-giving system. While the Macedonians vanished from the epigraphic record after the fourth century $\mathrm{BCE}$, so that their appearance is interpretable as

\footnotetext{
$87 \quad F d D 3.383(18$ о $/ 79$ ? 179/8? вСЕ).

88 Crowther 2006, 35 .

89 Ager 1996, 28; Fournier 2010, 536-542; Mack 2015, 264-266.

$90 \quad$ Magnetto 2013, 33.

91 On theoric networks, see Rutherford 2007, 23-37. See Chapter 3.

92 See below.
} 
a brief trend, the subsequent Roman rhythm dominated the Delphic honorific culture for nearly 300 years.

\section{$2.2 \quad$ The Economy of Honours}

The occurrence of different rhythms and trends succinctly demonstrates that the practice of granting honours at Delphi adapted to changes in the social milieu. Voted gifts evolved from the standard package consisting of proxenia, promanteia, proedria, prodikia, asylia and ateleia, as was characteristic of Hellenistic Delphi, to statues which became the most commonly awarded gift in the Roman period. Over time, however, both the popularity of particular honours and their respective value changed, which sheds some light on prestige deflation and the local hierarchies of honours.

The social prestige of any awarded honour depended on multiple criteria: the honour's symbolic value, its financial cost for the polis and the benefits reaped by the recipient. First of all, civic honours were divided into those that conferred upon their recipients palpable benefits and those of a solely prestigious character. Privileges such as ateleia (exemption from public burdens), citizenship, the right to own land (enktesis) and the right to pasture (epinomia), and the enjoyment of civic rights (epitimia) all offered distinct material advantages to foreign residents or foreigners with economic ties to the polis. In contrast, honours such as commendation, proedria (standing reservation of front-row seats at performances), the setting up statues or the dedication of crowns on one's behalf generated social capital and appealed to the recipient's vanity but brought no material gain..$^{93}$ The non-material nature of the second class of honours did not detract from their perceived importance, since, for example, grants of honorific portraits, proedria and citizenship were thought to count among the highest honours (megistai timai) conferred in Athens. ${ }^{94}$ For the ancient Greeks, material profits granted by honorary functions mattered just as much as the benefits which such honours added to the recipient's social status. For physical gifts such as statues and crowns, their value to the recipient and the community rested on their awe-inspiring visual splendour, artistic worth and the amount of public attention they attracted.

Second of all, the perceived value of honours depended on their economic cost. Crowns, statues, daily banquets, financial endowments and other gifts for foreigners (xenia) incurred considerable expenses that the polis (or private

93 Domingo Gygax 2016, 40.

94 Gauthier 1985; Oliver 2007, 183-200; Biard 2017, 96-101. 
individuals) had to meet. ${ }^{95}$ The relative cost of bestowing an honour was contingent on the economic situation of the city. The same type of gift cost more during a period of regression than during a period of prosperity. The contingency of an honour's cost also made a particular difference to grants of land and money. For example, in Demosthenes' speech Against Leptines (20.115), the orator draws attention to the fact that civic grants of land and money, which were gifted in the fifth century вСЕ to Lysimachos, son of Aristides, did not seem extraordinary for the affluent Athenians of that time. In the fourth century, however, as the economic condition of the Athenian polis worsened, only a third of the goods once granted to Lysimachos would have constituted an extraordinary, if not decadent, reward. ${ }^{96}$ Similarly, when the Delphic polis gifted 500 drachmas to Polygnota after it had been ravaged by the Mithridatic Wars, the city's generosity must have counted more than it would have in the more prosperous Delphi of the third century. ${ }^{97}$ In fact, the exceptional significance of Polygnota's recognition could explain why the text of the decree specified the sum of funds granted, which is a rare occurrence in the local epigraphic habit. ${ }^{98}$

Third of all, the value of a gift depended on the esteem accorded to it. The increase in citizen numbers in Roman Delphi, which has already been considered in this chapter, devalued the significance of citizenship grants. In economic terms, one could speak of the ongoing deflation of status of these honours. With the increase of supply, the value of gifts decreased. A similar deflation of citizenship status took place in classical Athens. Politeia awarded to foreign benefactors in the fifth century ВСЕ mattered more than politeia granted in the fourth century $\mathrm{BCE}$, because securing Athenian citizenship opened more doors in the fifth century вСЕ. ${ }^{99}$ Appropriately, even grants of statues gradually lost prestige over time. Honorific portraits, as rewards to outstanding individuals such as military leaders, heroes or victorious athletes, appeared in the archaic period as a coveted civic prize. At some point in the Hellenistic period, the range of recipients of such statues widened, whereas

\footnotetext{
95 Camia 2017, 109.

96 Domingo Gygax 2016, 41.

$97 \quad F d D$ 3.249 (86 BCE). See Bélis 1999, 53-55; Chaniotis 20o9, 87-91; Choix 2012, nos. 208209. For female artists at Delphi, see Perrot 2013, 195-210. For artists honoured at Delphi between the fourth century BCE and the third century CE, see Bouchon 2013, 171-193.

98 Another rare example of a specific monetary reward survives in a decree honouring a harpist from Kyme in Aeolis, Syll 689 (134 BCE).

99 Dem. 23.199-200; Domingo Gygax 2016, 41.
} 
in Roman times the custom of awarding statues became commonplace. ${ }^{100}$ Heller and van Nijf rightly observe that honorific portraits in the imperial times had long ceased to denote an exceptional reward for exceptional deeds; their bestowal had become a routine and token acknowledgement of civic gratitude. ${ }^{101}$ Since privileges remain privileges by virtue of being limited, the rise in the number of granted statues automatically decreased their value.

Shifts in the value of honorific decrees at Delphi allow one to make several general observations concerning the local economy of honours. First, classical and Hellenistic gifts that were granted to the Delphic benefactors appear more valuable and varied than those granted in the Roman era. By the Augustan period, grants of promanteia, proedria or ateleia became a rarity; theorodokia, invitations to the prytaneion and xenia were no longer granted; honours such as proxenia, raising statues and grants of citizenship lost much of their former esteem. Among these honours, statues diminished most visibly in their significance. At Roman Delphi, any relatively affluent and connected individual with links to the civic council could arrange to have his honorific portrait raised, while the Delphi of yesteryear reserved such honours for extraordinary statesmen, generals and athletes in the archaic and classical periods, expanding the group of recipients with public benefactors in the Hellenistic era. ${ }^{102}$ Second, the subjection of Delphi to Rome brought about some measure of decrease in the number of grants of particular gifts. As discussed above, from the late Hellenistic era onwards the Delphic honorific habit revolved around the Romans. During this era, emperors and high-ranking Roman magistrates became the dominant category of the recipients of Delphic honours. ${ }^{103}$ Moreover, the upheaval in the social dynamics of granted honours forced Greek poleis to adapt and adjust their local honorific traditions. Significantly, neither the Roman officials nor the emperors needed the honorary distinctions that were voted by the Greek cities in the Hellenistic period, since both groups ex officio enjoyed priority in consulting the oracle or the right to sit in the front seats in the theatre. Instead, Roman gifts took the monumental form of buildings and statues, effecting changes within Greek honorific culture and simultaneously adjusting to them. The citizens of Greek poleis, being forced to ingratiate themselves with the new territorial power, adapted local honorific practices to meet Roman standards and expectations.

\footnotetext{
100 Mattusch 1988; Hintzen-Bohlen 1992; Connelly 2007; Oliver 2007, 181-204; Ma 2013; Griesbach 2013, 83-124; Queyrel and Hoff 2017; Grzesik 2019, 200-227.

101 Heller and van Nijf 2017a, 13.

102 Biard 2017, 29-74.

103 Grzesik 2019, 210-212.
} 
Having considered several criteria according to which honorific gifts were assigned value in particular contexts in Delphi, I now proceed to examine their relative hierarchy. Since Roman-era grants present a severely skewed epigraphic milieu with rare grants of packages of privileges, I investigated the hierarchies of honours in the more representative Hellenistic milieu. Gangloff's 2017 study convincingly argues that honours differed in terms of the prestige they granted, with public praise regarded as the least prestigious and the raising of a statue as the most coveted. ${ }^{104}$ Assigning unequal significance to honours was aimed at diversifying the prestige economy and compelling benefactors to give more and more generously to the polis. Fittingly, Kuhn observed that benefactors gave more eagerly and often if there were additional, prestigious honours to be won. ${ }^{105}$ The diversification of the value of civic honours therefore encouraged, on a more permanent basis, political agon between members of the elite, as the top echelons of the society competed for higher distinctions. The competitive character of this honorific culture both built on and, in turn, productively channelled internal rivalries among the elites into civic-minded initiatives: sponsoring games, festivals, theatre performances, distribution of money or food. In accordance with the characteristic features of the Greek agon, benefactors desired to outdo other contributors even more if the resultant gifts of honours would elevate them to higher positions than their peers. ${ }^{106}$ In other words, the hierarchic honorific system exploited and flattered human vanity in a controlled and altruistic manner. One could simultaneously contribute to the common good of one's community and win a right to portray oneself as better than one's fellow citizens.

\subsection{Gifts for Citizens and Non-citizens}

The citizens of Delphi were eligible for fewer types of gifts than others, since they could not be granted politeia or proxenia. My analysis of the honorific habit indicates that the Delphians had no interest in receiving honours that by design accorded civic privileges to foreigners (e.g. prothysia, epitimia or isopoliteia), since the Delphians already enjoyed these rights by virtue of their citizenship. ${ }^{107}$ On the same note, the Delphians already had right of precedence

\footnotetext{
104 Gangloff 2017, 59-8o. See also Heller and van Nijf 2017a, 5-6.

105 Kuhn 2017, 201.

106 Bielfeldt 2012, 93-94; Zuiderhoek 2017, 182.

107 The privileged position of the citizens of Delphi in their polis is reflected in many phrases used in honorific decrees, see fn. 50 in Chapter 1.
} 
in access to their oracle (promanteia) ${ }^{108}$ In an earlier study, Pouilloux recognised the following order in the act of consulting the oracle: the Delphians came first, then representatives of communities and private individuals who were granted the right of promanteia, then members of the Amphictyony and other allied cities, after them the states outside the Amphictyony, and, finally, the 'barbarians'. 109

Given that the Delphians found many of the traditional decrees unsuitable to their circumstances, it stands to reason that their polis celebrated their contributions in another manner. In Athens, the most common gifts for the Athenians were crowns and public praise - rewards which were not related to monetary gain, but which were very prestigious all the same. ${ }^{110}$ In contrast, only two Delphic honorific decrees mention honours bestowed on private Delphians. ${ }^{111}$ It appears that honorific culture beyond Athens prioritised foreigners over citizens, with comparable trends being observable on Delos and Crete. ${ }^{112}$ The two aforementioned honorific Delphic decrees were granted in the Roman era to Archelaos, son of Hyginos, and Memmios Neikandros. The former received a commendation at Delphi $c .8 \mathrm{O}-95 \mathrm{CE} .{ }^{113}$ The latter received an extremely rare gift of hero worship in the second quarter of the second century CE. ${ }^{114}$ Along with his cult in the prytaneion, Neikandros obtained four statues set up in Delphi, Olympia, Argos and Corinth. The dating of these two outlying decrees to the Roman period ought not to surprise us when one considers that the first records of the Delphic polis which set up public honorific portraits for its citizens appear only at the juncture of the first century BCE and the first century CE. ${ }^{115}$ For this reason, a significant transformation

\footnotetext{
$108 \quad F d D$ 4.375.

109 Pouilloux 1952, 484-513.

110 Domingo Gygax 2016, 227.

111 The citizens of Delphi issued an honorific decree (SGDI 2647, 224-220 BCE) for Hermias, son of Charixenos, who is also known from the Amphictyonic document (SGDI 2524, 226 вСE). From the text of the Amphictyonic decree it is known that Hermias lived in Delphi

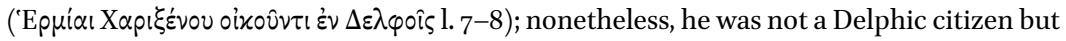
a synoikos and consequently he is not mentioned among the Delphic citizens who were granted Delphic honours. See Choix 2012, no. 102; Flacelière 1937, 337; Rousset 2002, 226.

112 Gauthier 1985, 32-33.

$113 F d D 3.233$.

$114 F d D$ 1.466. See Grzesik 2015, 281-285. Bousquet $(1966,466)$ presents one parallel example, when a citizen of Megalopolis was awarded hero worship and statues in Olympia, Nemea, Isthmia and Megalopolis.

115 The earliest document is $F d D 4.25$ O (25 BCE-25 CE), while four examples are dated to the first century CE and seven to the second century CE, see Grzesik 2019, 204-205. One honorific inscription for the citizen of Delphi dates to the second century вСЕ ( $F d D$ 4.245); the granting authority, however, did not survive.
} 
must have occurred in the Delphic gift-giving system under the Romans, with honours previously reserved for foreigners now being awarded to local elites. Significantly, Neikandros and Archelaos both possessed vast wealth and held the most cost-incurring civic offices: Archelaos acting as a gymnasiarch, and Neikandros serving as a xystarches. ${ }^{116}$ Archelaos' father, Hyginos, a native of Corinth, came to Delphi in $c .5^{\circ} \mathrm{CE}$ and was granted Delphic citizenship shortly afterwards, ${ }^{117}$ which elevated his status to that of bouleutes. ${ }^{118}$ In turn, Memmios Neikandros descended from a line of priests and priestesses: his father, Gaius Memmios Euthydamos, was a priest of Apollo and Plutarch's peer at the oracular temenos. ${ }^{119}$ An illustrious citizen, Gaius Memmios Euthydamos served as a Delphic archon no less than three times between 79 and 95 CE. ${ }^{120}$ His mother, Memmia Lupa, held the eminent office of archeis - priestess of Apollo -, ${ }^{121}$ while her father, P. Memmios Soter, began the family tradition of holding the priesthood of Apollo. ${ }^{122}$

The material allows us to draw several conclusions concerning the bestowal of Delphic honours to Delphic citizens. In Hellenistic times, no Delphic citizen received Delphian privileges, since all Delphians enjoyed the same prerogatives, obviating the need for additional gifts. In the imperial period, many members of the Delphic elite received Delphic honours. ${ }^{123}$ However, Roman Delphi witnessed a growth in inequality as its citizenry stratified and its level of civic privilege diversified. Honorific images set up in the imperial period for local elite members led to the reinforcement of the social and political superiority of local aristocrats (super-citizens) in comparison to regular citizens. By elevating honorands above their peers, the statues brought them closer to the gods and underlined their greatness. As in Delphi, so in other poleis of the Roman era, local diplomats, magistrates or holders of liturgical offices replaced foreign benefactors as the chief recipients of honours. The cast of the honorific social nets shrank, turned inward and spread in the direction and manner of Rome. ${ }^{124}$

\footnotetext{
116 Curty 2015, 239-248.

$117 \quad F d D 4.88$.

$118 F d D$ 4.114.

119 Puech 1992, 4849.

$120 F d D 6.132$ and 133. The first archonship is dated to $c .75 \mathrm{CE}$, the second archonship to c. 80-90 CE ( $F d D$ 3.233, FdD 4.100 and 4. 113), and the third archonship to $c .95 \mathrm{CE}$.

$121 F d D 1.466$ and $F d D 6.2$ and 6.3a. Bourguet $(1905,18)$ identifies archeis ( $\dot{\alpha} p \times \eta i \varsigma)$ with hiereia (iepsi $\alpha$ ) but Jannoray $(1946,257-259)$ argues that the title of archeis had a somewhat broader meaning and also applied to other duties.

122 Bourguet 1905, 13; Puech 1992, 4849; Grzesik 2015, 282-283.

123 Grzesik 2018b, 117-139.

124 Bielfeldt 2012, 92-93.
} 


\subsection{Conclusion}

For centuries, Delphic honorific culture shaped the city's foreign policy, facilitating interactions with the Greek world and lands beyond. Post-classical Delphi had a political system, enacted its own decisions, and managed its institutions, negotiating, either with territorial powers or with other poleis, its history, status, and issues of internal and external significance. An array of official honorific documents, impressive in volume and variety, testifies that neither Delphi nor any other Greek city were mere pawns in the chess game of the Hellenistic kings and Rome, but played an important role in contemporary historical developments. As Lambert rightly notices in the case of Athens, so too, in Delphi, honorific decrees placed in particular locations (usually within the civic spaces) stood as a monumentalised form of diplomacy, and the study of honorific documents has the potential to cast a powerful light on the changing priorities of city's foreign policy. ${ }^{125}$

The records of honorific titles granted en masse create a rare opportunity to observe in fine detail the Delphic network of honours, the ongoing deflation of some gifts, and the changing value of other honours. From the mid-fourth century BCE until the turn of the Common Era, the Delphic gift-giving system centred on foreigners originating from all corners of the Mediterranean world. After the Romans began to dominate the political landscape and Greek peer-polity interaction declined, the Delphians preferred to confer honours on prominent Romans and on their own elite citizens. This adjustment resulted, inter alia, in the modification of the Delphic gift-giving system: honorific statues became the most popular honours, in lieu of the previously popular decrees which granted standard packages of honours. Thus, the honorific documents from Delphi offer a lively and detailed snapshot of not only the networks linking Delphi to the Greek world but also internal rivalries and tensions within the sacred polis itself.

125 Lambert 2012, 96. 